\title{
The Bakassi Dispute: People’s Dynamics and the rise of Militancy
}

\author{
Hindatu Maigari Yerima ${ }^{1}$ D.S Ranjit Singh ${ }^{2}$
}

\begin{abstract}
Nigeria and Cameroon have long standing cordial relations even before the coming of the Europeans. With the coming of the imperialists and subsequent colonization of the Africa, borders were created albeit artificially which became source of dispute between African states and Nigeria and Cameroon as well. The dispute endured for a long period of time until when Cameroon took the case to the ICJ and settled in 2002. The case officially was over but the displaced people of the Peninsula who are neither happy with Nigeria nor Cameroon and it has become a source of concern to the Nigerian and Camerooniangovernments. They have evolved into militants and the rich and well-endowed Bakassi Peninsula is gradually becoming unavigable. This article will look at the current situation of the people and try to advance measures that may end the militancy without consuming more lives and properties.
\end{abstract}

Keywords: Bakassi, Nigeria, Cameroon, Border, Boundary, Delineation, militancy, treaty.

\section{INTRODUCTION}

1. The history of Nigeria- Cameroon relations goes way back before the First World War. Bakassi Peninsula lies between the Cross River estuary near the city of Calabar which is located in Nigeria in the west and the Rio del Rey estuary on the East. The Rio del Rey is a drainage basin located in West Africa within Equatorial Guinea and Cameroon (Familugba \& Ojo, 2013).The Peninsula is estimated to be 1,600km long, bordering the area between Nigeria and Cameroon which extend from Lake Chad to the Gulf of Guinea. It has a rough population index that ranges from 150,000 to 300,000. The people of Bakassi are mainly from Calabar, Cross Rivers and Akwa Ibom States of Nigeria. The major ethnic groups that occupy the peninsula are the Ibibio, Efik, Ekoi, Semi-Bantu and Bantu people (Njuko, 2013).Therefore it's a great source of fishing which constitutes the major source of income for the inhabitants. These two countries share a lot of things in common from religions, cultures to languages. Bakassi region, being under the Obong of Calabar before the coming of the colonialists, and who signed away his Kingdom as a British Protectorate in 1862, became part of Nigeria in 1914 under British rule, which also marked the amalgamation of northern and southern protectorates to form one Nigeria. As Nigeria was not in existence before, the British took over regions and made them into protectorates. The northern region was ruled through indirect system of administration because as the time the British came, a system of government was already in place while southern part was ruled under small kingdoms Therefore, warrant chiefs were used by the Bristish to rule the region. It all ended when the amalgamation took place 1914 and a country with the name Nigeria was born.However, through a series of bilateral treaties and other legal instruments, the British ceded the territory, first to Germany, and then placed it under the mandate of the League of Nations and trusteeship of the United Nations (Tarlebbea and Baroni, 2010). Meanwhile the British protectorates in Nigeria, including the Kingdom of Calabar were merged with its colonies in the area, as one integrated British colony. Later, largely due to the political errors and indifference of Nigeria politicians, the Republic of Cameroon obtained the Bakassi Peninsula in the process of a plebiscite conducted by the United Nations in 1959 and 1961. By the same process, Nigeria also obtained some territories which formerly belonged to Cameroon.During the Presidency of Ahidjo of Cameroon(1960-1962) and the Nigeria's Military Government under General Gowon (1966-1975), Nigeria entered into peaceful engagement with Cameroon by setting up a Boundary Commission of Experts of both countries to look into the issues and proffer solutions. On June 1, 1975, a Treaty known as 'The Maroua Declaration' was signed by Cameroon and Nigeria purportedly to delimit the maritime boundary between the two countries from the point where the relevant colonial treaty ended, which extended down to the Cross River estuaries and out to sea to a point south of Bakassi. However, the interpretation of the Treaty was not acceptable to Nigeria, when it became clear that Bakassi Peninsular would be lost, due to her strategic-military and economic status, the political consequence and the population. Cameroon realized that Nigeria is going to renegade on their agreement, therefore armed with the treaty, Cameroon's engaged in hostilities with Nigeria in 1972-1973 and in May 1981 by invading Nigerian villages in the Adamawa Province and as well as Bakassi Peninsula, an act of provocation and probably to show Nigeria that she is willing to fight for the Peninsula, such actions prompted Nigeria to increase its naval and military presence in the Bakassi area and other parts of South-South and South-East Nigeria.(Jadesola,2012). 


\section{Research Objectives}

1 This research paper seeks to examine the outcome of the GTA on the Bakassi indigenes.

2 To also determine the fate of the returnees and their militancy in Nigeria.

3 To explore viable options of bringing an end to the suffering of the Bakassians.

\section{RESEARCH METHOD}

The method of data collection for this paper is qualitative in nature. Qualitative research is a method of inquiry that in most cases produces results in words rather than statistics (Bello, 2007). The emphasis on sources of data was historically based on primary data which is interview. Secondary data such as documents and analysis of documentary evidences which include government documents and reports Newspapers and Magazines; and internet was used for this paper.

\section{The ICJ ruling of 2002}

\section{DISCUSSION OF FINDINGS}

With the increase of Nigerian military and constant sporadic attacks continuing, the time was getting ripe for a faceoff between the two countries. General Sani Abacha took over power as head of state in 1991; the Nigerian government claimed that the Peninsula was still legally part of Nigeria. Cameroon countered the claim with an agreement signed during the Nigerian civil war (1967-1970) by Nigerian military ruler, Yakubu Gowon, which ceded the territory to Cameroon. Nigeria refuted the agreement and in early 1994, invaded the Peninsula. The turn of events eventually led Cameroon to take the matter to the International Court of Justice (ICJ) in 1994 following the occupation of the Bakassi territory by the Nigerian troops on 12 December 1993, (Francis, 2012). ICJ ordered both countries to cease hostilities. In October, 2002, the ICJ ruled that the Peninsula belonged to Cameroon on the basis of 1913 agreement, and ordered Nigerian forces to leave the area, however, they continued to occupy the region until the dispute was finally resolved in favour of Cameroon in 2006. In view of its geographical location, Bakassi Peninsula is strategically important to Nigeria. The area constitutes an external environment for defense. From Nigerian experience during the civil war of 1967-1970, it was clearly revealed that Nigeria political stability could be undermined by foreign enemy who could use the place as a base to destabilize the country. (Familugba \& Ojo, 2013)After the ICJ judgment in 2002, the Secretary General facilitated the formation of the Cameroon-Nigeria Mixed Commission which was to enable a smooth handing over ceremony. The Mixed Commission did their homework on the handing over logistics and a few years later on 12 June 2006, the two parties concluded the "Green Tree Agreement" and the handing over ceremony was done in front of UN officials and diplomats from numerous countries. The Green tree agreement was the implementation of the ICJ ruling, detailing the gradual withdrawal of the Nigeria and its military from Bakassi Peninsula. The agreement addressed the issue of human security and the rights of the inhabitants of the peninsula. Under the Agreement, the Nigerian troops were to withdraw within a maximum of ninety days and a transition period of two years was given for the Nigerian administration to be replaced by the Cameroonian administration. Nigerians living in the Peninsula would be able to remain there under a special regime for four years after Cameroon takes full control and could stay on after that if they so wish (Francis, 2012).

\section{BOUNDARY DEMARCATION}

Boundary demarcation is an imposition on the African people following the coming of the Europeans. Their lands were partitioned during the imperialist scramble for territories without recourse to the already existing boundaries between the Kingdoms. Adamawa Kingdom has its own boundary and has been living peacefully with all the tribes. The same goes to Borno Empire, the Efik Kingdom, the Kwararafa Kingdom, so also the Sokoto Caliphate. Some believed that the Europeans wanted to weaken those Kingdoms; therefore they decided not to involve the kings by drawing arbitrary lines cutting through all their territories. Consequently, you see that half of Adamawa is in Cameroon, sharing both the name of Kingdom and the kingship title and so goes to the other kingdoms. It was observed by the then Shehu(King) ofthe Borno Empire, Europeans thatcame to visit him were busy, on asking them what they were doing, they informed him that they were drawing boundary lines. He said how could they do that without informing him? He brought out an agreement signed and sealed between his Kingdom and the Sultan of Bagarmi's Kingdom in Chad, respecting the river sharing their boundaries. The Englishmaninformed the Shehu that the map he provided was 'rather late'. The arbitrary borders madethe delineation for the mixed commission more challengingsince the people have lived with their boundaries from generation to generation for centuries, peacefully with their neighbours respecting their streams and mountains as boundaries and then all of a sudden lines were drawn across them. This made them to lose their farmland, artifacts, totems etc. 


\section{The Plebiscite (1961)}

It should be noted that at Nigeria's independence on October 1, 1960, Bakassi was already under Cameroon. In 1961, a plebiscite was held to determine the preferences of the people of Cameroon as to whether to remain a part of Nigeria or to formally join the Cameroon. The outcome of this exercise showed that the majority of the Cameroonians preferred to join Northern Cameroon. In effect right from the Nigeria's First Republic to the end of the Nigeria Civil War Bakassi was governed as part of Cameroon (Okoli, 2009). To this, the Bakassians stated that they did not formally vote to move to Cameroon but they were simply carried along. According to Shettima, former director at the National Boundary Commission, Nigeria, he mentioned that "After the independence of both Nigeria and Cameroon in 1960, the German territory was given to Nigeria and Cameroon under the trusteeship mandate of the then League of Nation, they were neither part of Nigeria nor Cameroon. They have the right to determine where they want to be. That gave rise to the plebiscite for them to vote either to join Cameroon or Nigeria; they were not given option for independence. The vote was only done on two issues whether to join Nigeria or to join Cameroon. The southern part, around Bamenda, Buya, etc., opted to join Cameroon although, because of their relationship with Nigeria, they are English speaking people. The northern part from Mubi up to Lake Chad,decided to join Nigeria. They moved on their own, the votes was counted, the majority won, the minority held their own. If you go to Cameroon now, they are four million Nigerians living in Cameroon. These are those who voted to stay with Nigerian but because they are in minority, they could not win the election but they insisted on maintaining their citizenship (Nigerian citizenship). Some have stayed all their lives in Cameroon but have maintained their Nigerian nationality. (NBC, 2015).

\section{After the GTA (2006)}

It is estimated that 90 percent of the inhabitants of Bakassi are Nigerians of Efik extraction. Most Nigerians in Peninsula are either traders or fishermen, (Idumange, 2010). After the ICJ ruling, the government of Nigeria has made effort to relocate and has relocated some of the former citizens of Bakassi who opted to go back to their Bakassi because the Nigerian Government has failed in integrating in the new settlements. But some, refused to leave being that their means of livelihood rely on the creeks and tributaries of the river for fishing and other related activities. For those that stayed behind, life was made almost unbearable by the nonconformity of the Green tree agreement on the part of Cameroon. Their basic rights as citizens were taken away from them, such as freedom of movement, access to the rivers for their fishing and heavy tax was levied against Bakassi inhabitants who are mostly Nigerians by the Cameroonian authority.Therefore the issue of human security rose to the fore. Human security refers the safety and sustainability of social, ecological and material conditions that sustain human life (Okoli, 2015). The human security situation in the Bakassi Peninsula since the ICJ intervention and ruling has been dire and complicated. The deplorable state of human security in the area, particularly as it relates to the Nigerian residents on the Bakassi is briefly highlighted in the sub-themes that follow.

Police Brutality: Nigerian residents on the Bakassi Peninsula have been severally harassed and brutalized by the Cameroonian security and/or law enforcement operatives. Apart from the sporadic aggression perpetrated by the Cameroonian Army, there have been cases of police molestation against Nigerians resident in Bakassi area. For instance on October 16, 2009, Cameroonian gendarmes were reported to have killed six Nigerians fishermen in the Bakassi territorial waters (Gustavo, 2013). It has also been reported that Cameroonian authorities have hoisted Cameroonian flags in Nigeria villages, while also obliging Nigerians to change their names and assume Cameroonian identity (Gustavo, 2013).

Citizenship crisis: The Nigerian residents in the Bakassi area are largely Efike people of the old Calabar kingdom. Since the ceding of Bakassi to Cameroon, these people have been left in a state of citizenship crisis. They neither legitimately belongs to Nigerian nor Cameroon. In effect, they have been in a state of "near statelessness" (Gustavo, 2013). The residents who were resettled in Nigeria have persistently complained of poor governmental attention, especially concerning their material wellbeing (Okoli, 2013).

Loss of livelihood: The Bakassi residents are largely fishermen and traders whose livelihood depends largely on the maritime resources available on the territorial waters of the peninsula. Their relocation to the main land of Nigeria has meant displacement from their traditional sources of livelihood. Consequently, they have been subjected to livelihood crisis, which affects their general living condition.

Population displacement: Population displacement has been a critical outcome of the Bakassi conflict in the aftermath of ICJ ruling. It is estimated that more than 60,000 residents have been displaced in the area (Oluda, 2011). The displaced population is highly vulnerable to material hardship and is exposed to dire social and economic vulnerabilities in their various camps in Nigeria. Associated with this is the issue of social dislocation whereby families and households have been dislodged and relocated from their ancestral domains. The displaced families live in varying degrees of humanitarian crisis and material destitution as a result. 


\section{The returnees}

On the whole, the plight of the Bakassi residents in the aftermath of the ICJ ruling has been appalling. It has been a case of human security challenge, complicated governments neglect. The desperate situation in which these residents have found themselves has been captured rather appropriately thus: All in all, the suffering goes two ways; the population that decided to stay in the peninsula has been attacked and persecuted by the Cameroonian security forces; on the other hand, the situation of those who decided to flee into Nigeria has not been appropriately addressed, resulting in a desperate situation. Regarding the latter, Bakassi people who fled to Nigeria - whether by their own will or by force - have not been given conditions to exercise their traditional livelihoods, nor the right to vote for local or national elections in Nigeria. These people have become what can be called of "near - stateless people" (Gutavo, 2013:para.11 as cited in Okoli, 2013:15).As it is, the fate of the Bakassi residents in the aftermath of the ICJ ruling has been more of the dilemma of continuous torment. They have been constantly persecuted by the Cameroonian forces in sharp violation of the Green Tree Agreement. On the other hand, they have also been obviously neglected by the Nigerian authorities who have largely failed to ensure their protection and wellbeing since the handover of the disputed Bakassi (Babatola, 2012). This has resulted in the creation of the much dreaded militants today in the Bakassi region. According to Hon. Elizabeth Ironbar, the constituency member of Akpabuyo Local Government Area, in which the new Bakassi is located, in an interview, stated that the case has not been laid to rest. The oil politics has cost the Bakassians their land and source of livelihood.These young men have been denied a source of honest living therefore they took to militancy which is both on land and on the waters. Kidnappings have become so rampant even the locals now are not spared. Although some of them chose to do menial jobs across the region but assimilation has become a big problem which the Nigerian and the Cross River state government are not doing much about. She opined that:

'Without that particular oil, nobody will fight over that land. There is a lot of oil in that land. It is a gold mine. Right now there are people that are drilling underground. They laid pipes underground deep in to the sea. I can authoritatively tell you that. From time to time you will be seeing their vessels emptying in to their tanks. And, our traditional leaders are involved, because that is what they want.'

It appeared that a system of corruption and thievery has been perfected in that oil laden area. All the stake holders prefer to line their pockets rather doing the needful by fully supporting and integrating the returnees into the society. As a result, in October 2012, 20 indigenes of Bakassi in Cross River State of Nigeria, under the Free Bakassi Association filed a suit against the Federal Government of Nigeria at a Federal High Court in Abuja with a prayer to void the Green Tree Agreement that ceded the oil-rich Bakassi to Cameroon (Babatola, 2012:90). This affirms the desperate condition of the residents of Bakassi who have been left in a state of citizenship crisis and neglect over the years. 